\title{
Korrespondensie
}

\section{Aanwas versus oorskot}

Vergun my die geleentheid om kommentaar te lewer oor die redaksionele bydrae van B.J. Meyer in die S.A. Tydskrif vir Natuurwetenskap en Tegnologie 3, no. 1, 1984 ,,Veroudering en die ou mens - feite en fabels."

Wanneer, volgens die outeur, 'n diersoort se lewensduur geneties bepaal is dan is sy lewensfunksies daarmee saam ook geneties bepaal. Dus behoort lewensfunksies en lewe gelyktydig op te hou.

Een van die belangrikste lewensfunksies van enige spesie is sekerlik reproduksie, want die voortbestaan van die spesie is daarvan afhanklik. Weismann' skryf in 1889 dat daar by diere ' $n$ korrelasie bestaan tussen die reproduksievermoë en die duur van die lewe van die individu binne ' $n$ spesie en diere leef in werklikheid vir die vereiste tyd en nie langer nie. $E^{2}{ }^{2}$ was en is dit steeds eens met Weismann.

Neem ons die hoofkomponente van die genoemde lewensfunksie by die mens, naamlik puberteit, swangerskap en menopouse, dan het hierdie tydperk binne sekere grense oor eeue heen konstant gebly ten spyte daarvan dat tot tans 26 jaar bygevoeg is by die jare wat die lewensverwagting aan die begin van hierdie eeu was. Hierdie komponente en die lewensfunksie is dus geneties bepaal. By die vrou begin en eindig die menopouse tussen die jare 45 en 50 en word die lewensfunksie voltooi. Dit mag bloot toevallig wees dat hierdie ouderdom ooreenstem met die lewensverwagting aan die begin van die eeu, maar ons weet ook dat sedertdien die kennisontploffing, die bevolkingsontploffing en noem dit maar die ouderdomsontploffing hand aan hand gaan. Die outeur sê self ,,die mediese het jare by die lewe gevoeg" en beaam Plato ${ }^{3}$ se woorde van lank gelede: ,And so dying hard by the help of science he struggled on to old age."

Dit blyk dat die mens die enigste spesie in die klas Mammalia is wat die stadium van menopouse bereik en dit oorleef. Die ander diere sterf klaarblyklik voordat hierdie stadium beriek word. ${ }^{4.5,6,7}$ Met die toevoeging van jare na die voltooiing van hierdie lewensfunksie skep Homo Sapiens dus vir hom 'n tweede lewe, hoe kunsmatig van aard dit ook mag wees, hoe reg of verkeerd.

Wanneer teen die jaar 2025 die 60 -jarige en ouer persoon die aantal jongmense sal oortref, sal dit reeds vroeër gebeur het dat die oúer as die reproduksielewe en die jónger as die reproduksielewe 50:50 tel. Sou dit 'n normale distribusie wees en 'n ware balans tussen lewe en dood weerspieël?

Wie gaan in watter stadium bepaal waarmee ons die dade wil vul: die oues van dae of die jongmense wat nou moet plek maak vir die bogenoemdes, maar terselfdertyd na hulle sal moet omsien en die voortbestaan van die spesie sal moet verseker?
Dit is so dat die mens vandag op 60 en 65 nog ,,jonk oud" is, aangesien hy hom vir hierdie „tweede lewe" goed voorberei het. Eerstens benut hy sy reproduksielewe van ongeveer 33 jaar maar baie spaarsaam en beskerm en bewaar hy sy liggaam op dié wyse. Vandag se vrou bring 1-4 kinders in die wêreld, maar hoe sou sy lyk na 25 of meer? Tweedens word die normale verouderingsaanslae op die liggaam wat hulle verskyning maak na die jare 30 , suksesvol afgeweer, behandel en derhalwe uitgestel.

In die proses van ,,jare by te voeg" het selfs 'n natuurlike dood 'n rariteit geword, want vandag sterf die mens letterlik oor 'n tydperk van weke, maande en selfs jare. Nie dat dit die keuse van die individu is nie. Vandag is ' $n$ noodlottige einde omtrent die natuurlikste dood denkbaar. Myns insiens faal die mediese wetenskap wanneer dit lyding verleng, die sterwende oor 'n lang tydperk aan die lewe hou, en hom blootstel aan onnodige behandeling, hom sy waardigheid ontneem en hom sinneloos laat voortbestaan tot die dood dan tog uiteindelik intree.

Daar is 'n duidelike pleidooi vir 'n hoër aftreeouderdom en ek wonder net wat gaan die werkloosheidsyfer teen die jaar 2000 en 2025 wees en watter ouderdomsgroep dit sal betrek? Of glo ons dat die reeds oorbevolkte aarde met sy vinnig kwynende hulpbronne maar net kan aanhou om nuwe werksgeleenthede te skep?

Om nog 37 jaar te wil byvoeg om die lewensverwagting met die maksimale lewensplan te balanseer, kan niemand se erns wees nie. Ek het reeds voorheen gewaarsku ${ }^{8,9}$ en ek waarsku weer dat die strewe na 'n fisiologies moontlike of blykbaar geprogrammeerde maksimale lewenspan ons duur te staan sal kom en dat ons moet volstaan by vandag se prestasie wat lewensduur betref.

Dit moet tog duidelik wees dat die oorbevolkingsprobleem twee oorsake het, naamlik aanwas en oorskot. Tot nog toe word die natuurlike proses van aanwas laer en laer gedwing om 'n onnatuurlike oorskot te regverdig om binnekort te veroorsaak dat die oues die jonges in getalle sal oortref.

Indien ons sou voortgaan met hierdie poging sal daar in die jaar 2025 of selfs vroeër ' $n$ bedreiging vir wêreldvrede wees wat veel groter is as enigiets wat vandag bestaan, naamlik 'n konfrontasie tussen jeug en ouderdom.

\section{LITERATUUR}

1. Weismann, A. (1889). Essays upon heredity and kindred biological problems. Authorised translation by E.B. Poulton, S. Schonland \& A.E. Shipley. (Clarendon Press, Oxford.)

2. Petrick, S.W. (1976). Parameters van lewensiklusse by soogdiere, hulle onderlinge korrelasies en die implikasies daar- 
van in die Veeartsenykunde. Proefskrif: Universiteit van Pretoria.

3. Griffin, J.J. (1949). Plato's philosophy of old age. Geriatrics, 4, 242-255.

4. Asdell, S.A. (1964). Patterns of mammalian reproduction. 2nd ed. (Constable, London.)

5. Schultz, A.H. (1969). The Life of primates (Weidenfeld \& Nicolson, London.)

6. Roberts, S.J. (1971). Veterinary obstetrics and genital diseases (Edward Bros., Ann Arba, Michigan).

7. Hafez, E.S.E. (1980). Reproduction in farm animals. 4th ed.
(Lea \& Febiger Philadelphia.)

8. Petrick, S.W. (1977). Homo Sapiens op die gevaarlys. S.A. Med. Tydskrif, 102

9. Petrick, S.W. (1983). Die kanker van beskawing. S.A. Med. Journal, 63, 678.

\section{S.W. Petrick}

Departement Chirurgie, Universiteit van Pretoria, Posbus 12580, Onderstepoort, 0110 